\title{
Astrocytes in depression and Alzheimer's disease
}

\author{
Yang Liao ${ }^{1}$, Qu Xing ${ }^{2}$, Qianqian $\mathrm{Li}^{3}$, Jing Zhang ${ }^{1}$, Ruiyuan Pan $(\varangle)^{1}$, Zengqiang Yuan $(\bowtie)^{1}$ \\ ${ }^{1}$ The Brain Science Center, Beijing Institute of Basic Medical Sciences, Beijing 100850, China; ${ }^{2}$ School of Life Sciences, Zhengzhou \\ University, Zhengzhou 450001, China; ${ }^{3}$ School of Traditional Chinese Medicine, Beijing University of Chinese Medicine, Beijing 100029, \\ China \\ (C) The Author(s) 2021. This article is published with open access at link.springer.com and journal.hep.com.cn
}

\begin{abstract}
Astrocytes are an abundant subgroup of cells in the central nervous system (CNS) that play a critical role in controlling neuronal circuits involved in emotion, learning, and memory. In clinical cases, multiple chronic brain diseases may cause psychosocial and cognitive impairment, such as depression and Alzheimer's disease (AD). For years, complex pathological conditions driven by depression and AD have been widely perceived to contribute to a high risk of disability, resulting in gradual loss of self-care ability, lower life qualities, and vast burden on human society. Interestingly, correlational research on depression and AD has shown that depression might be a prodrome of progressive degenerative neurological disease. As a kind of multifunctional glial cell in the CNS, astrocytes maintain physiological function via supporting neuronal cells, modulating pathologic niche, and regulating energy metabolism. Mounting evidence has shown that astrocytic dysfunction is involved in the progression of depression and AD. We herein review the current findings on the roles and mechanisms of astrocytes in the development of depression and $\mathrm{AD}$, with an implication of potential therapeutic avenue for these diseases by targeting astrocytes.
\end{abstract}

Keywords astrocytes; depression; Alzheimer's disease; roles; mechanisms

\section{Introduction}

Astrocytes are identified as versatile glial cells and closely associated with other cell types in the brain. The conventional wisdom of astrocytes is "brain glue," which means that astrocytes were thought to function as a neuronal supporting matrix $[1,2]$. However, emerging evidence suggested that the function of astrocytes is far from supporting cells. They can interact with neurons and form tripartite synapses, playing a crucial role in maintaining stable neuronal function, including the regulation of extracellular fluid, ion homeostasis, ion transportation, cerebral blood flow, synaptic remodeling, and energy supply [3-6]. In addition, the endfeet of astrocytes together with vascular endothelial cells maintains the integrity of the brain-blood barrier (BBB) and provides a homeostatic environment for the brain [7]. Moreover, astrocytes can interact with microglia to respond to brain injury, bacterial infection, and other insults in the brain. The interplay

Received March 2, 2021; accepted May 29, 2021

Correspondence: Ruiyuan Pan, panruiyuan168@sina.com; Zengqiang Yuan, zyuan620@yahoo.com between astrocytes and microglia always couples in many neuroinflammatory diseases, including depression and Alzheimer's disease (AD) [8].

As a common chronic disease, depression is characterized by specific symptoms in human mental, emotional, and physical health such as sadness, low self-esteem or guilt, sleep disturbance, tiredness, attention deficit, and anhedonia [9-11]. Generally, symptoms of depression develop gradually, and patients frequently have an intention to self-injure or even commit suicide. Epidemiological studies have indicated that the prevalence of depression has increased over the past decades; depression has been estimated to affect more than 300 million people globally, nearly $4.4 \%$ of the world's population $[12,13]$. According to the World Health Organization reports, depression was ranked as the third cause of the global burden of disease and was expected to rank first by 2030 [14]. Unfortunately, the pathogenesis of depression is still unclear. Several hypotheses have been proposed to explain its pathogenesis. Among them, the monoamine neurotransmitter serotonin (5-hydroxytryptamine (5-HT)) hypothesis is the most widely investigated and appreciated [15]. 5-HT is synthesized from the essential amino acid tryptophan and produces physiologic effects by binding 
with seven broad families (5-HT1, 5-HT2, 5-HT3, 5-HT4, 5-HT5, 5-HT6, 5-HT7 receptor families) [16]. The 5-HT hypothesis affirmed that imbalance of 5-HT levels and dysfunction of 5-HT receptor families are involved in depression $[17,18]$. The significant functions of 5-HT in modulating normal neuronal development and excitability have already been proved [19,20]. Nevertheless, these speculations remain controversial. The diagnosis and treatment of depression are still a challenge to clinicians due to the uncertain pathogenesis.

$\mathrm{AD}$ is the most common degenerative disease in the elderly and is characterized by progressive cognitive impairment [21]. With the acceleration of the global aging population, the number of patients with $\mathrm{AD}$ is rapidly increasing. More than 100 million people worldwide are predicted to suffer from AD by 2050 [22-25]. However, the pathogenesis of $\mathrm{AD}$ remains unclear. The primary hypotheses of $A D$ are the amyloid- $\beta(A \beta)$ cascade hypothesis and tau protein hypothesis. The $A \beta$ cascade hypothesis proposes that the accumulation of $A \beta$ results from the imbalance of $A \beta$ production and clearance. Subsequently, $A \beta$ accumulation caused by either $A \beta$ overproduction or $A \beta$ clearance impairment would finally rise to neurotoxicity [26-28]. The tau protein hypothesis postulates that tau protein hyperphosphorylation leads to neurofibrillary tangles (NFTs) and subsequent neuron loss $[29,30]$.

Although the pathogenesis of depression and $\mathrm{AD}$ is mainly based on hypotheses, both diseases have many similarities. Interestingly, mounting evidence suggested that depression may be a risk factor or even a prodrome of AD [31-33]. Postmortem studies and other medical investigations showed that abnormal morphological and functional astrocytes appear in the development of depression and AD [34-37]. Therefore, we propose that astrocytes may be involved in the pathogenesis of these two diseases, and restoring astrocytic homeostasis would be a new avenue for treating them.

\section{Astrocytes in depression}

\section{Astrocytes regulate energy metabolism in the development of depression}

Normal energy metabolism is essential for neuron network homeostasis. Generally, neurons consume $80 \%-90 \%$ of total energy in the central nervous system (CNS) [38]. The neuronal energetic substrates, glucose and lactate, mainly stem from capillaries and astrocytes and are delivered through glucose transporters (GLUTs) and monocarboxylate transporters (MCTs), respectively [39-41]. Precisely, lactate produced in astrocytes can instantly deliver abundant energy to satisfy the neuronal requirements
[40,42]. Astrocytes take up glucose from surrounding capillaries via GLUT1 and store it in the form of glycogen. By contrast, neurons are weak in energy storage [43]. They release glutamate during neuronal transmission to stimulate glycogen catabolism, aerobic glycolysis, and lactate production in nearby astrocytes, and then astrocytes release lactate via MCT1 or MCT4 [44,45]. This process is named astrocyte-neuron lactate shuttle (ANLS) and is posited to support neuronal plasticity and excitability [43,46-50].

Emerging evidence demonstrated that metabolism disorder is involved in the pathogenesis of depression [51]. Experiments conducted in mice exhibited temporary increases in extracellular lactate in the brain when mice were exposed to the forced swimming test. These lactates were found to be derived from astrocytes and involved in neuronal excitability and synaptic plasticity [52]. We can regard this phenomenon as an instant energy compensation to neuronal stress, which verifies the function of rapid energy supply about lactate [53]. Carrard et al. have increased hippocampal lactate levels through peripheral administration of lactate, which induced antidepressantlike effects. The injection of lactate downregulates glycogen synthase kinase-3 $\beta$ (GSK-3 $\beta$ ) and cAMP response element binding protein (CREB) phosphorylation, which is akin to the effect of certain antidepressant drugs such as lithium [54]. Lactate upregulates synaptic plasticity-related genes such as activity-regulated cytoskeletal protein (Arc), c-fos, and Zif268 [55] (Fig. 1). Lactate administration also amplifies 5-HT signaling by increasing p11 (a binding protein for a 5-HT receptor) and increases the expression of astrocyte marker S100 $\beta$ [54]. These results indicate that astrocytes may be a mediator of the antidepressant-like effects of lactate by regulating 5-HT receptor trafficking [54,56]. Subsequently, experiments carried out by Karnib et al. also verified the antidepressive effects of lactate. Similar to Carrard et al., they applied peripheral injection of lactate to mice susceptible to chronic social defeat stress (CSDS), strengthening resilience and rescuing social avoidance behavior and anxiety in mice [57].

There are still controversial opinions on the ANLS hypothesis because it lacks direct evidence of lactate transportation from astrocytes to neurons. For example, the cellular location of lactate consumption in the brain remains unclear, and neurons also use other approaches to obtain energy besides MCTs, such as glucose transport systems $[58,59]$. Notwithstanding, astrocyte-derived lactate is indispensable for neuronal energy consumption and plasticity [43]. Even though neurons can use glucose as a direct energy source, astrocyte-derived lactate is predominantly required to maintain normal physiologic activities [40]. Together, as an energy substrate, astrocyte-derived lactate is a significant mediator and potential target for treating depression. 


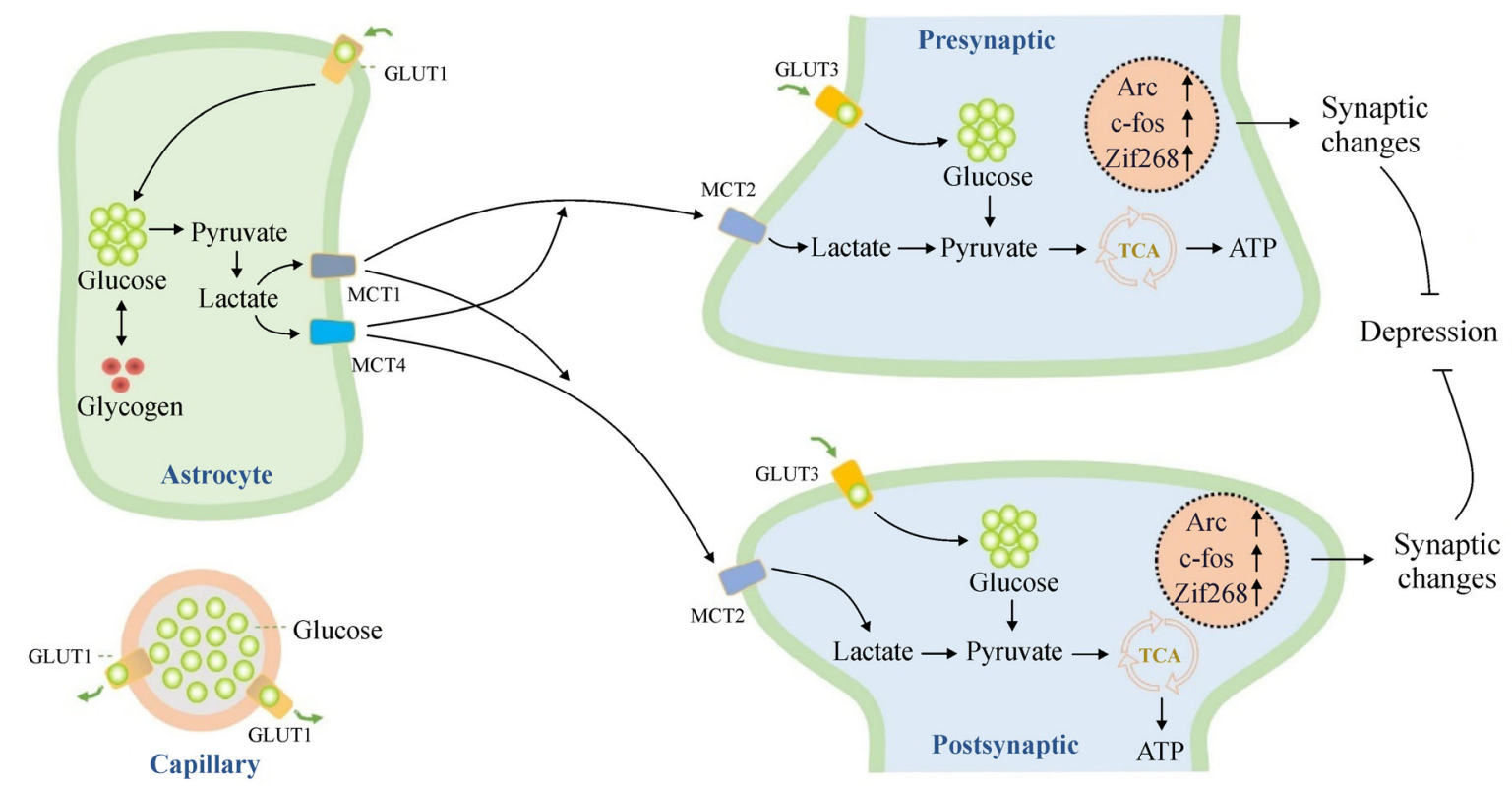

Fig. 1 Diagram of ANLS in depression. Astrocytes take up glucose from the capillary via GLUT1, store it by converting it into glycogen, or catabolize it into pyruvate by glycolysis. Pyruvate can be converted into lactate, which is then delivered into neurons through MCTs. The uptake of astrocyte-derived lactate by neurons is converted to pyruvate. Glucose from the capillary can also be absorbed in neurons via GLUTs and is then catabolized into pyruvate, which is fed into the TCA cycle for energy production and participates in synaptic plasticity and depression development. MCTs, monocarboxylate transporters; GLUT, glucose transporter; TCA, tricarboxylic acid cycle.

\section{Astrocyte-derived adenosine $5^{\prime}$-triphosphate (ATP) is associated with depression}

ATP, a multifunctional molecule, was initially recognized as an energy transfer medium [60]. However, recent studies revealed that ATP plays vital roles not only in neuronal energy metabolism but also in neuronal plasticity. Notably, ATP serves as a gliotransmitter or neuromodulator to modulate functional neuronal homeostasis when the extracellular concentration of ATP is low in normal conditions. P2XR-mediated ATP energetic transmission has been found in CNS synapses [61,62]. Correspondingly, insufficient ATP results in impaired synaptic plasticity in the progression of depression [63-67]. Vesicular ATP released from astrocytes is a significant source of extracellular ATP in the brain to maintain neuronal function $[63,68]$. Cao et al. found that the ATP level was remarkably decreased in the prefrontal cortex (PFC) in CSDS model mice. Accordingly, the regional injection of ATP into the medial PFC (mPFC) produced an antidepressant-like effect without impacting murine locomotor activity. Moreover, Cao et al. concluded that ATP binding with $\mathrm{P} 2 \mathrm{X} 2 \mathrm{R}$ in the $\mathrm{mPFC}$ is required for the antidepressant role of ATP [63]. Astrocytic exocytosis of ATP can also govern neuronal dopamine (DA) release in developing depression-like syndrome [69]. Taken together, astrocytederived ATP acts as a neuromodulator to modulate depressive-like behaviors.

In addition to the vesicular ATP-releasing mechanism, researchers are eager to search the specific ATP-releasing channel proteins. CALHM1/2, two calcium homeostasis modulator (CALHM) family proteins, contain four-pass transmembrane domains and recently have been identified as an ATP-releasing channel [70-74]. Ma et al. found an apparent reduction of astrocytic ATP release in CALHM2 knockout mouse [72]. Deficiency of ATP release alters spine morphology and plasticity, which induces depressive-like syndrome in mice $[72,75]$. Furthermore, similar phenotypes were observed in the astrocyte-specific CALHM2 deficiency mice, further supporting that CALHM2 regulates depression-like behaviors as an astrocytic ATP-releasing channel [72].

However, an apparent increase in extracellular ATP in the brain, mainly derived from dead cells and reactive astrocytes, is associated with pathological changes (such as stress and cellular injury) [76,77]. Moreover, these ATPs non-selectively bond with microglial $\mathrm{P} 2 \mathrm{X} 7$ receptor (P2X7R), which leads to the efflux of $\mathrm{K}^{+}$, thereby inducing NLRP3 inflammasome assembly, caspase-1 stimulation, and cytokine interleukin-1 (IL-1 $\beta$ ) maturation and release $[78,79]$. Therefore, treatment with $\mathrm{P} 2 \mathrm{X} 7 \mathrm{R}$ antagonists, elimination of NLRP3, or blockade of peripheral IL-1 $\beta$ could rescue depression caused by chronic stress $[78,80,81]$. Furthermore, ATP has been reported as a "danger signal" or a "warning molecule" in the brain, which interacts with purinergic receptors such as P2X7R, P2Y1R, and A2AR in brain disorders $[82,83]$.

Overall, astrocytic ATP plays important roles in 
neuronal function, which might be involved in depression (Fig. 2). On the one hand, homeostatic astrocytes maintain physiologic levels of extracellular ATP, which supports neuronal viability and synaptic plasticity. On the other hand, reactive astrocytes release excessive ATP into the extracellular matrix and subsequently activate nearby microglia through the $\mathrm{P} 2 \mathrm{X} 7$ receptor, resulting in the activation of the NRLP3 inflammation and thus neurotoxicity. Therefore, ATP is an important mediator that connects astrocytes and depression. Although the mechanisms of ATP involvement in the development of depression remain to be explored, we can conclude that astrocytederived ATP in low level and physiologic dose is fundamental for maintaining normal physiologic function.

\section{Astrocyte-mediated neuroinflammation modulates depressive-like syndrome}

Brain immunity depends on astrocytes and microglia due to the BBB. Astrocytes, together with microglia, regulate the immune system in the brain and escort BBB function. Neuroinflammation is usually regarded as the activation of astrocytes and microglia, both of which switch to a state of pro-inflammation to release a vast number of proinflammatory cytokines $[84,85]$. In addition to ATPmediated neuroinflammation that has been described above, astrocytes participate in regulating various inflammatory signal transductions. There are several signaling pathways of astrocyte-mediated neuroinflammation, such as gp130, TGF $\beta R$, IFN $\gamma R$, ER $\alpha$, A20, STAT3, FasL, and BDNF; the upregulation of these signaling pathways in astrocyte is usually recognized as an anti-inflammatory response; on the contrary, the activation of Act1, S1P1, B4GALT6, TrkB, NF-кB, SOCS3, CCL2, CXCL10, or VEGF signaling pathways is a pro-inflammatory effect [86]. Therefore, astrocytes are a "double-edged sword" in the case of neuroinflammation, performing detrimental and protective functions. Astrocyte ablation has been shown to cause severe neuroinflammation in experimental autoimmune encephalomyelitis (EAE) or brain injury in mice [87-89]. However, another study showed that astrocyte depletion improved neuroinflammation in the chronic phase of EAE [90]. Whether astrocytes play a beneficial or a detrimental role depends on their state. Astrocyte activation is the main cause of neuroinflammation.

Depression is commonly accompanied by neuroinflammation, which causes the activation of microglia and astrocytes, lessens brain serotonin, activates the hypothalamic-pituitary-adrenal axis, and impairs synaptic plasticity and neurotransmission [91-94]. In rodent models, lipopolysaccharide (LPS) is frequently adopted to induce depression-like behaviors by producing severe neuroinflammation [95-98]. Specifically, Leng et al. discovered that the expression of multiple endocrine neoplasia type 1 (Men1; protein: menin) is decreased in the brain of mice subject to chronic unpredictable mild
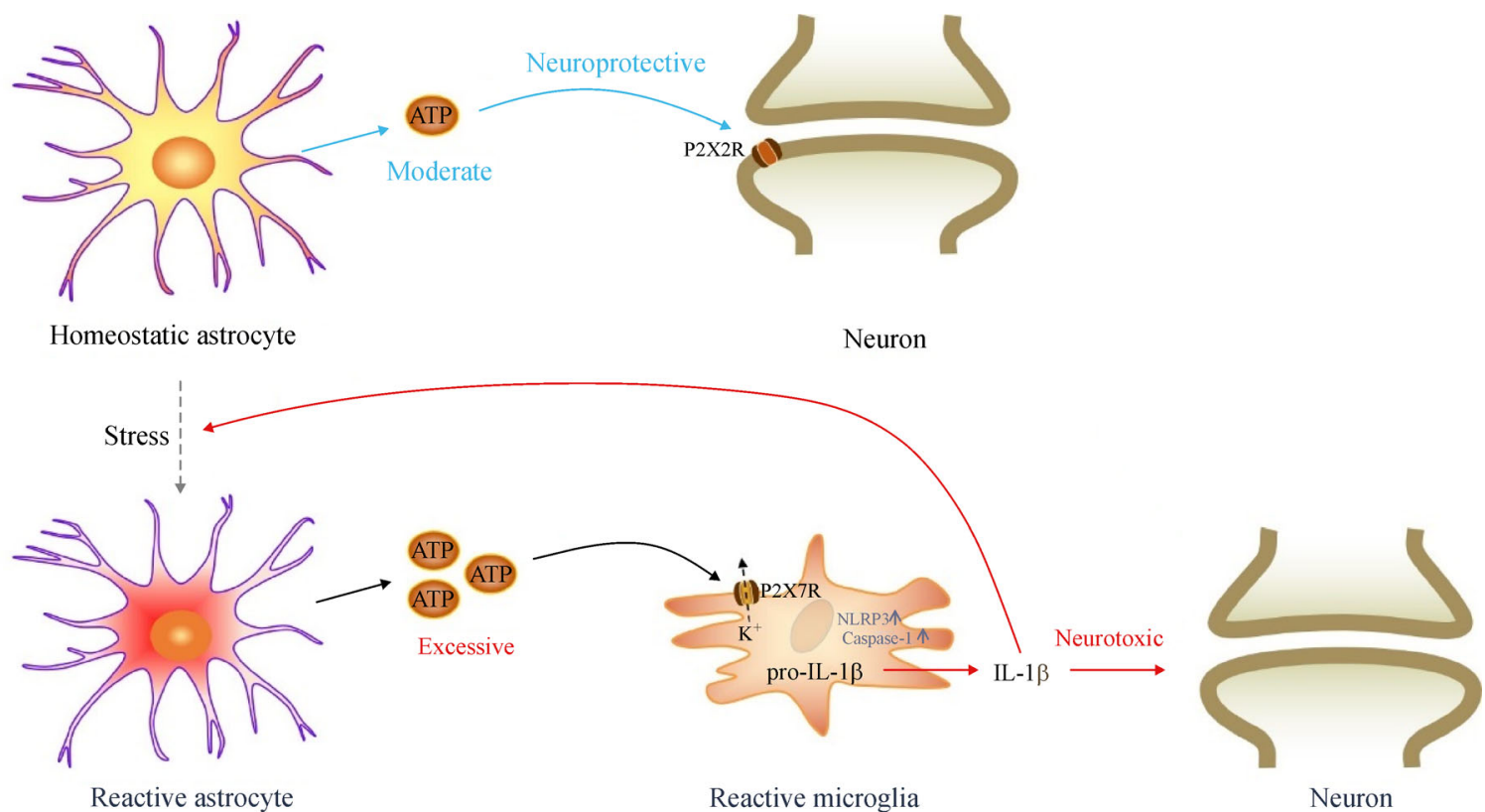

Fig. 2 Astrocyte-derived ATP plays a dual role in neuronal function. Due to the significantly different receptor affinities in normal circumstances (P2X2 is100-fold > P2X7), ATP released from homeostatic astrocytes serves as a neurotransmitter or neuromodulator, which binds with P2X2R in neurons, maintaining neuronal morphology, excitability, and plasticity. By contrast, when astrocytes are activated under pathological conditions, they produce excessive ATP, binding with P2X7 in microglia, followed in sequence by the upregulation of NLRP3 and caspase-1, release of IL-1 $\beta$, and finally neuroinflammation and neurotoxicity. 
stress and LPS-induced neuroinflammation. Moreover, they found that astrocyte-specific menin deficits promote NF- $\kappa B$-induced IL- $1 \beta$ upregulation, resulting in morphological abnormalities and synaptic deficits in neurons and depression-like behaviors in mice. Interestingly, they found an association between MEN1 mutations and major depressive disorder risk in humans [99]. Other studies also supported the view that astrocyte-mediated neuroinflammation is involved in depression pathology. LPS-induced astrocyte activation can cause depressionlike behaviors, which can be alleviated by inhibiting astrocyte reaction [100-102].

Taken together, neuroinflammation is a crucial link or even a prerequisite in the progression of depression. Thus, neuroinflammation can be regarded as a standing point to seek antidepression strategies. Specifically, reducing astrocyte activation might be a considerable approach.

\section{Astrocytes in AD}

\section{Astrocytes are closely involved in amyloid pathology}

Being abundant in the CNS, the role of astrocytes in AD has received less attention and appreciation compared with microglia [103]. However, along with the recognition of the connection between astrocytes and $\mathrm{AD}$, astrocytic roles in the development and progression of $\mathrm{AD}$ are attracting more attention.

During the progression of $\mathrm{AD}, \mathrm{A} \beta$ originates from amyloid precursor protein (APP) and plays a central role in AD pathogenesis. APP is cleaved by beta-site APP cleaving enzyme 1 (BACE1), which yields SAPP $\beta$ and a cell-membrane-bound fragment (C99). Then, C99 is cleaved by $\gamma$-secretase, which releases $A \beta$ and amyloid intracellular domain. $A \beta$ aggregation was thought to be the significant event that drives the progression of $\mathrm{AD}$ pathology, which mainly exists in the extracellular matrix in the brain, followed by glial reaction, neuroinflammation, neurotoxicity, neuronal cell death in the hippocampus and gray matter, and eventually memory impairment and dementia [104-106].

Post-mortem AD brain tissue analysis has shown that reactive astrocytes are accumulated around $A \beta$ deposits [107-109]. After exposure to $A \beta$, similar to microglia, astrocytes are polarized to the A1 status and subsequently release cytokines (such as IL-1 $\beta$ or IL-6), nitric oxide, reactive oxygen species, and excessive glutamate [110 113]. The series of neurotoxicity or excitotoxicity eventually evolves into neuron loss and neurodegeneration. Furthermore, the expression of BACE1 was found in astrocytes, which indicates that astrocytes may be involved in $A \beta$ aggregation [114]. To identify the astrocytic source of $\mathrm{A} \beta$, Veeraraghavalu et al. dissociated primary astrocytes from the brains of newborn PS1 $\Delta$ E9flox or APPswe mice and 8-week-old APPswe/PS1 $\triangle$ E9flox mice. They detected the expression of $A \beta$ secreted by astrocyte in a culture medium, which could be prevented by the treatment of $\gamma$ secretase inhibitor [115]. Taken together, it would be a vicious cycle accelerating disease progression: $A \beta$ induces reactive astrocytes, and then reactive astrocytes, in turn, promote $\mathrm{A} \beta$ aggregation and $\mathrm{AD}$ pathogenesis.

\section{Astrocytes influence tau protein accumulation in AD progression}

Microtubule has been verified to be a vital component of neuronal cytoskeleton protein, involved in nutritional support of neuronal bodies and axons. As an effective form of microtubule-associated proteins, tau is a critical component of a microtubule. Moreover, tau has crucial physiologic functions in modulating microtubule, including microtubule polymerization and stabilization and its normal structural function. However, hyperphosphorylated tau aggregates can cause NFT generation, microtubule dysfunction, and finally neuronal death, which are the significant pathologies of AD [116-118].

In addition to neuronal tau accumulation, astrocytic tau accumulation also exists and plays a pivotal role in $\mathrm{AD}$ pathology $[119,120]$. Current evidence indicated that $3 R$ isoforms of tau rather than $4 \mathrm{R}$ tau are responsible for tau aggregation [121,122]. Specifically, Richetin et al. have proved that the accumulation of $3 R$ tau in hilar hippocampal astrocytes is related to $\mathrm{AD}$ severity in individuals [123]. Astrocyte-specific overexpression of 3R tau impairs normal mitochondrial distribution and functions in hilar astrocytes and disturbs the hippocampal neuronal network in vivo, which in turn damage hippocampal function. Correspondingly, mice with astrocytic 3R tau accumulation exhibit a spatial memory deficit [123]. Moreover, hyperphosphorylated tau aggregates are promoted by senescent cell accumulation, which drives neurodegenerative disease, while removing senescent glial cells, including astrocytes and microglia, could attenuate tau phosphorylation [124]. Therefore, astrocytic tau protein or astrocyte-promoting tau accumulation plays an essential role in tau pathology during the development of $\mathrm{AD}$, indicating that astrocytes could be a crucial target in $\mathrm{AD}$ treatment. Hence, the underlying mechanism of astrocytes in tau pathogenesis needs to be systematically studied.

\section{Astrocytes impact AD progression via regulating energy metabolism, extracellular ATP release, and neuroinflammation}

Akin to depression, ANLS impairment can also be observed in the progression of $\mathrm{AD}[56,125]$. A recent study demonstrated that expressions of MCTs (MCT1, MCT2, and MCT4) and lactate-relevant enzymes (lactate 
dehydrogenase A) are decreased in the cortex and hippocampus of APP/PS1 mice [126]. Suzuki et al. also reported that disruption of MCT1, MCT2, or MCT4 expression impairs synaptic plasticity and long-term memory, while recovery of lactate transport between astrocytes and neurons can rescue these defects [49]. Intriguingly, ATP has been shown to control A $\beta$ aggregation in AD progression [127]. Jung et al. showed that astrocyte-derived ATP might prevent neuronal plasticity impairment and dendritic spine loss in the pathology of $A \beta$ [128].

In addition, astrocyte-mediated neuroinflammation is involved in AD [129-133]. Alleviation of astrocytic reaction driven by adeno-associated virus ameliorates $A \beta$ pathology, modulates synaptic plasticity, and improves cognition in AD model mice [134]. Interestingly, Katsouri et al. demonstrated that ablation of astrocytes increases $A \beta$ levels, affects synaptic and neuronal density, and induces memory deficits in mice [135]. These studies indicated the crucial role of astrocytes in inflammation-related diseases, including AD. Maintaining normal astrocytic function and decreasing its activation might prevent the occurrence of $\mathrm{AD}$.

\section{Astrocytes, a promising therapeutical target for depression and AD}

Antidepressant drugs such as selective serotonin reuptake inhibitors (SSRIs) and DA agonists might exert neuroprotective effects through astrocytes [136-138], given that astrocytes express 5-HT receptors (e.g., 5-HT1A and 5HT7), glial serotonin transporter (SERT), and dopaminergic receptors (e.g., D1R and D2R) [139-142]. For example, SSRIs and tricyclic antidepressants can downregulate the expression of astrocytic neurotransmitter transporters, such as SERT, leading to the increased level of 5-HT [143,144]. Interestingly, fluoxetine (a typical SSRI) can target astrocytes and increase the release of BDNF in hippocampal astrocytes and extracellular ATP level in vivo [145]. Other antidepressants such as imipramine and paroxetine can also upregulate BDNF mRNA expression in a primary culture of hippocampal astrocytes [145]. Moreover, treatment with antidepressants can significantly change the BDNF and glial cell linederived neurotrophic factor (GDNF) level in patients with depression [146]. BDNF and GDNF are two nutritional factors mainly derived from glial cells, which play an important role in the survival and function of midbrain DA neurons, and might be involved in the progression of depression [147,148]. In addition, DA can bind with astrocytic D1, mediating excitatory synaptic regulation [142]. The activation of the astrocytic dopamine 2 receptor can suppress neuroinflammation in the CNS [139]. Altogether, these findings indicated that antidepressant drugs could execute their pharmacological effects not only directly on neurons but through regulating astrocytes. Interestingly, these mentioned drugs or molecules might have effects on depression and AD.

SSRIs, which are typically administered as antidepressant drugs, have been shown to reduce $A \beta$ deposition in $\mathrm{AD}$ mice and patients [149]. Specifically, fluoxetine administration can improve spatial learning and memory functions in $\mathrm{AD}$ mice by mitigating hippocampal neuron loss, decreasing $A \beta$ level, inhibiting GSK-3 $\beta$ activity, and upregulating the level of $\beta$-catenin $[150,151]$.

DA, an excitability-related neurotransmitter, is downregulated or dysfunctional in depression $[152,153]$. DA receptor agonists such as aripiprazole and cariprazine can effectively alleviate depressive symptoms [154]. Interestingly, DA receptor expression is lower in AD individuals $[155,156]$. Accordingly, DA agonists could restore synaptic plasticity in AD patients [157]. Similar to SSRIs, a dopaminergic system-relevant therapeutic strategy has been proposed as a potentially effective treatment for $\mathrm{AD}$ [157-159].

Taken together, numerous pathophysiological mechanisms mediated by astrocytes are involved in depression and $\mathrm{AD}$; in other words, astrocytes are a potential linker between depression and $\mathrm{AD}$ as they are involved in the development of both diseases, indicating that astrocytes might be a potential therapeutic target for the treatment of depression and $\mathrm{AD}$.

\section{Conclusions and perspectives}

This review collected and summarized evidence to show how astrocytes participate in the development of depression and AD (Fig. 3). On the one hand, as a kind of multifunctional glial cells, homeostatic astrocytes secrete a range of factors, including ATP, BDNF, and growth factors, maintaining neuronal viability and synaptic plasticity. On the other hand, pathogenic astrocytes release toxic factors that promote cell death or cytokines and chemokines that cause neuroinflammation $[160,161]$. Mounting evidence has suggested that astrocytes are actively involved in various neuropathological processes, including depression and AD.

We herein conclude that astrocytes modulate energy metabolism, extracellular ATP, and neuroinflammation in the progression of depression. Concurrently, astrocytes also govern the above processes and $A \beta$ aggregation and tau protein accumulation in the pathology of AD. The dysfunction of astrocytes in depression and AD implies a correlation between depression and AD. Interestingly, both diseases share numerous similar epidemiological characteristics in addition to similar molecular and pathological changes. For example, depression is regarded as a risk factor or even a prodrome for $\mathrm{AD}[31,162,163]$. 


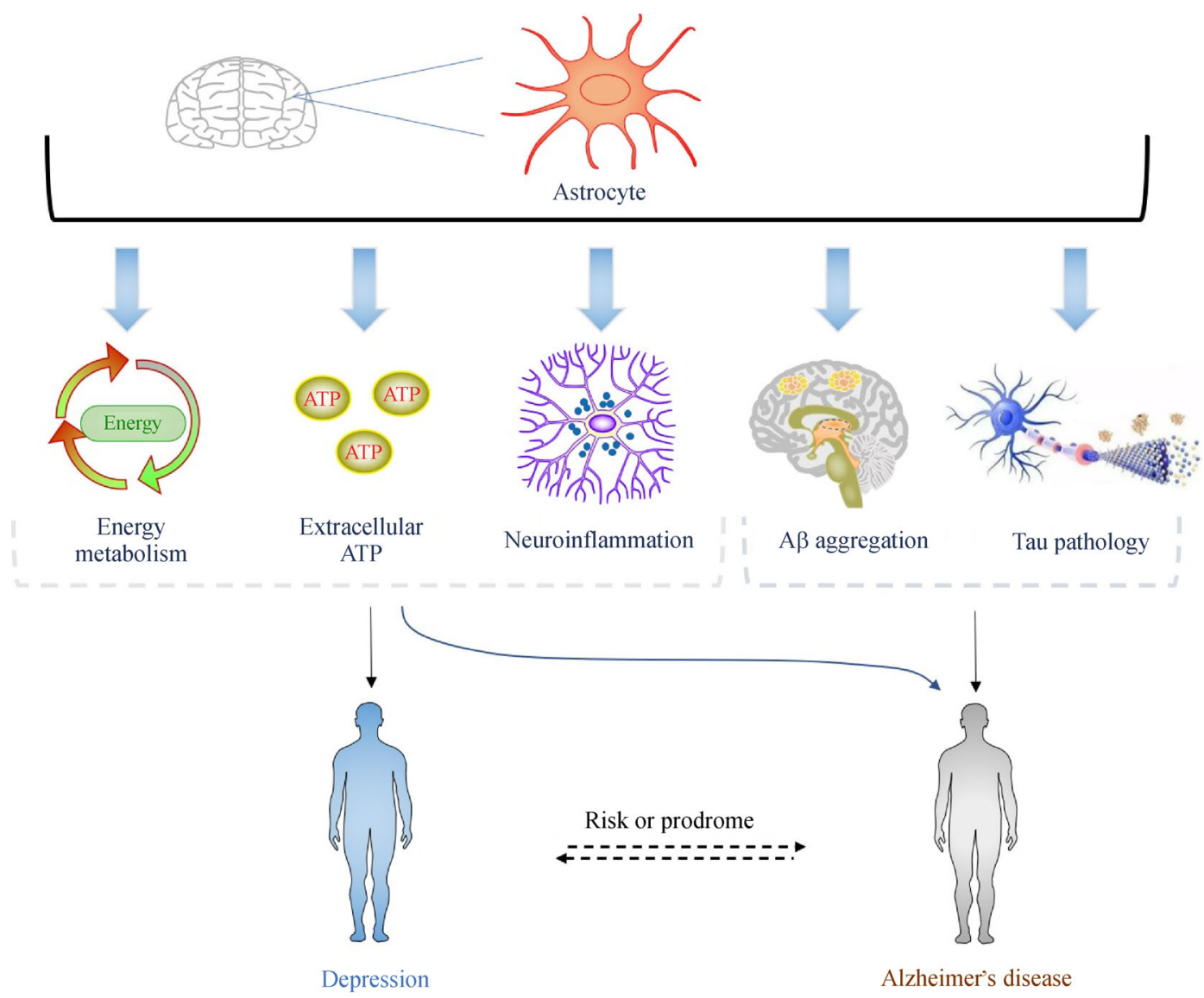

Fig. 3 Summary of this review. Astrocytes modulate extracellular ATP, neuroinflammation, and energy metabolism in the progression of depression. In addition, astrocytes regulate the above physiologic processes and $\mathrm{A} \beta$ aggregation and tau protein hyperphosphorylation in the pathology of $\mathrm{AD}$. The multiple roles of astrocytes in depression and $\mathrm{AD}$ might link depression and $\mathrm{AD}$. Increasing evidence showed that depression is thought to be a risk factor or prodrome of $\mathrm{AD}$. $\mathrm{A} \beta$, amyloid- $\beta$.

Furthermore, depression increases the risk of heart disease, stroke, and neuroinflammation, all of which are regarded as high-risk factors of AD [164-166]. Although mounting evidence has presented both relationships in a clinical setting and basic research, direct evidence showing that early depression causes AD is still lacking. Therefore, the relationship between depression and $\mathrm{AD}$ remains to be further investigated.

Importantly, the diagnosis and treatment of depression and $\mathrm{AD}$ remain challenging. The current drugs are insufficient to cure both diseases because of inadequate treatment outcomes and unpredictable side effects [167]. We herein propose a possible treatment of these two diseases by targeting astrocytes. For example, focal transplantation of healthy astrocytes in the brain has been proposed to be a promising therapeutic method for depression [168]. The engraftment of astrocytes producing a neuroprotective effect and cognitive enhancement has been verified in a rodent model $[169,170]$. Recently, Zhou et al. and Qian et al. found that efficient astrocyte-neuron conversion by genome editing to generate new neurons in the mouse brain can replenish the lost neuron in neurodegenerative disease. This method was demonstrated to alleviate motor dysfunctions in mice with Parkinson's disease $[171,172]$. Thus, genome editing-induced astrocyte-neuron conversion might also be a promising therapeutic method for neurodegenerative disease, including AD. Taken together, given the multiple functions of astrocytes in depression and AD that have been reviewed above, we argue that targeting astrocytes to maintain their functional homeostasis would be a potential strategy for treating these diseases.

\section{Acknowledgements}

All authors listed have made a substantial, direct, and intellectual contribution to the work, and approved it for publication. We sincerely thank the National Natural Science Foundation of China 
(Nos. 81930029, 81630026, and 81501200) and the Beijing Nature Science Foundation (No. 7161009). We deeply apologize to the authors whose work have not been cited due to the space limitation.

\section{Compliance with ethics guidelines}

Yang Liao, Qu Xing, Qianqian Li, Jing Zhang, Ruiyuan Pan, and Zengqiang Yuan declare that the research was conducted in the absence of any commercial or financial relationships that could be construed as a potential conflict of interest. This manuscript is a review article and does not involve a research protocol requiring approval by the relevant institutional review board or ethics committee.

Open Access This article is licensed under a Creative Commons Attribution 4.0 International License, which permits use, sharing, adaptation, distribution and reproduction in any medium or format, as long as you give appropriate credit to the original author(s) and the source, provide a link to the Creative Commons license, and indicate if changes were made.

The images or other third party material in this article are included in the article's Creative Commons license, unless indicated otherwise in a credit line to the material. If material is not included in the article's Creative Commons license and your intended use is not permitted by statutory regulation or exceeds the permitted use, you will need to obtain permission directly from the copyright holder.

To view a copy of this license, visit https://creativecommons.org/ licenses/by/4.0/.

\section{References}

1. Araque A, Parpura V, Sanzgiri RP, Haydon PG. Tripartite synapses: glia, the unacknowledged partner. Trends Neurosci 1999; 22(5): 208-215

2. Volterra A, Meldolesi J. Astrocytes, from brain glue to communication elements: the revolution continues. Nat Rev Neurosci 2005; 6(8): 626-640

3. Blanco-Suárez E, Caldwell AL, Allen NJ. Role of astrocytesynapse interactions in CNS disorders. J Physiol 2017; 595(6): 1903-1916

4. Khakh BS, Sofroniew MV. Diversity of astrocyte functions and phenotypes in neural circuits. Nat Neurosci 2015; 18(7): 942-952

5. Stogsdill JA, Ramirez J, Liu D, Kim YH, Baldwin KT, Enustun E, Ejikeme T, Ji RR, Eroglu C. Astrocytic neuroligins control astrocyte morphogenesis and synaptogenesis. Nature 2017; 551(7679): 192-197

6. Khakh BS. Astrocyte-neuron interactions in the striatum: insights on identity, form, and function. Trends Neurosci 2019; 42(9): 617630

7. Campisi M, Shin Y, Osaki T, Hajal C, Chiono V, Kamm RD. 3D self-organized microvascular model of the human blood-brain barrier with endothelial cells, pericytes and astrocytes. Biomaterials 2018; 180: 117-129
8. Liddelow SA, Marsh SE, Stevens B. Microglia and astrocytes in disease: dynamic duo or partners in crime? Trends Immunol 2020; 41(9): 820-835

9. Alexopoulos GS. Depression in the elderly. Lancet 2005; 365(9475): 1961-1970

10. Cui R. Editorial: a systematic review of depression. Curr Neuropharmacol 2015; 13(4): 480

11. Gaynes B. Assessing the risk factors for difficult-to-treat depression and treatment-resistant depression. J Clin Psychiatry 2016; 77(Suppl 1): 4-8

12. Wang J, Wu X, Lai W, Long E, Zhang X, Li W, Zhu Y, Chen C, Zhong X, Liu Z, Wang D, Lin H. Prevalence of depression and depressive symptoms among outpatients: a systematic review and meta-analysis. BMJ Open 2017; 7(8): e017173

13. World Health Organization. Depression and Other Common Mental Disorders: Global Health Estimates. Geneva: World Health Organization, 2017

14. Malhi GS, Mann JJ. Depression. Lancet 2018; 392(10161): 2299 2312

15. Boku S, Nakagawa S, Toda H, Hishimoto A. Neural basis of major depressive disorder: beyond monoamine hypothesis. Psychiatry Clin Neurosci 2018; 72(1): 3-12

16. David DJ, Gardier AM. The pharmacological basis of the serotonin system: application to antidepressant response. Encephale 2016; 42(3): 255-263 (in French)

17. Oxenkrug G. Serotonin-kynurenine hypothesis of depression: historical overview and recent developments. Curr Drug Targets 2013; 14(5): 514-521

18. Takahashi S. Reduction of blood platelet serotonin levels in manic and depressed patients. Folia Psychiatr Neurol Jpn 1976; 30(4): 475-486

19. Rojas PS, Fiedler JL. What do we really know about $5-\mathrm{HT}_{1 \mathrm{~A}}$ receptor signaling in neuronal cells? Front Cell Neurosci 2016; 10: 272

20. Teixeira CM, Rosen ZB, Suri D, Sun Q, Hersh M, Sargin D, Dincheva I, Morgan AA, Spivack S, Krok AC, Hirschfeld-Stoler T, Lambe EK, Siegelbaum SA, Ansorge MS. Hippocampal 5-HT input regulates memory formation and Schaffer collateral excitation. Neuron 2018; 98(5): 992-1004.e4

21. Naharci MI, Buyukturan O, Cintosun U, Doruk H, Tasci I. Functional status of older adults with dementia at the end of life: is there still anything to do? Indian J Palliat Care 2019; 25(2): 197202

22. Alzheimer's Association. 2016 Alzheimer's disease facts and figures. Alzheimers Dement 2016; 12(4): 459-509

23. Jia J, Wei C, Chen S, Li F, Tang Y, Qin W, Zhao L, Jin H, Xu H, Wang F, Zhou A, Zuo X, Wu L, Han Y, Han Y, Huang L, Wang Q, Li D, Chu C, Shi L, Gong M, Du Y, Zhang J, Zhang J, Zhou C, Lv J, Lv Y, Xie H, Ji Y, Li F, Yu E, Luo B, Wang Y, Yang S, Qu Q, Guo Q, Liang F, Zhang J, Tan L, Shen L, Zhang K, Zhang J, Peng D, Tang M, Lv P, Fang B, Chu L, Jia L, Gauthier S. The cost of Alzheimer's disease in China and re-estimation of costs worldwide. Alzheimers Dement 2018; 14(4): 483-491

24. Pan RY, Ma J, Kong XX, Wang XF, Li SS, Qi XL, Yan YH, Cheng $\mathrm{J}$, Liu Q, Jin W, Tan $\mathrm{CH}$, Yuan Z. Sodium rutin ameliorates Alzheimer's disease-like pathology by enhancing microglial amyloid- $\beta$ clearance. Sci Adv 2019; 5(2): eaau6328 
25. Realdon O, Rossetto F, Nalin M, Baroni I, Cabinio M, Fioravanti R, Saibene FL, Alberoni M, Mantovani F, Romano M, Nemni R, Baglio F. Technology-enhanced multi-domain at home continuum of care program with respect to usual care for people with cognitive impairment: the Ability-TelerehABILITation study protocol for a randomized controlled trial. BMC Psychiatry 2016; 16(1): 425

26. Barage SH, Sonawane KD. Amyloid cascade hypothesis: pathogenesis and therapeutic strategies in Alzheimer's disease. Neuropeptides 2015; 52: 1-18

27. Cline EN, Bicca MA, Viola KL, Klein WL. The amyloid- $\beta$ oligomer hypothesis: beginning of the third decade. J Alzheimers Dis 2018; 64(s1): S567-S610

28. Selkoe DJ, Hardy J. The amyloid hypothesis of Alzheimer's disease at 25 years. EMBO Mol Med 2016; 8(6): 595-608

29. Bakota L, Brandt R. Tau biology and tau-directed therapies for Alzheimer's disease. Drugs 2016; 76(3): 301-313

30. Eftekharzadeh B, Daigle JG, Kapinos LE, Coyne A, Schiantarelli J, Carlomagno Y, Cook C, Miller SJ, Dujardin S, Amaral AS, Grima JC, Bennett RE, Tepper K, DeTure M, Vanderburg CR, Corjuc BT, DeVos SL, Gonzalez JA, Chew J, Vidensky S, Gage FH, Mertens J, Troncoso J, Mandelkow E, Salvatella X, Lim RYH, Petrucelli L, Wegmann S, Rothstein JD, Hyman BT. Tau protein disrupts nucleocytoplasmic transport in Alzheimer's disease. Neuron 2018; 99(5): 925-940.e7

31. Mirza SS, Wolters FJ, Swanson SA, Koudstaal PJ, Hofman A, Tiemeier H, Ikram MA. 10-year trajectories of depressive symptoms and risk of dementia: a population-based study. Lancet Psychiatry 2016; 3(7): 628-635

32. Burke AD, Goldfarb D, Bollam P, Khokher S. Diagnosing and treating depression in patients with Alzheimer's disease. Neurol Ther 2019; 8(2): 325-350

33. Novais F, Starkstein S. Phenomenology of depression in Alzheimer's disease. J Alzheimers Dis 2015; 47(4): 845-855

34. Cobb JA, O’Neill K, Milner J, Mahajan GJ, Lawrence TJ, May WL, Miguel-Hidalgo J, Rajkowska G, Stockmeier CA. Density of GFAP-immunoreactive astrocytes is decreased in left hippocampi in major depressive disorder. Neuroscience 2016; 316: 209-220

35. Lemoine L, Saint-Aubert L, Nennesmo I, Gillberg PG, Nordberg A. Cortical laminar tau deposits and activated astrocytes in Alzheimer's disease visualised by ${ }^{3} \mathrm{H}$-THK 5117 and ${ }^{3} \mathrm{H}$-deprenyl autoradiography. Sci Rep 2017; 7(1): 45496

36. Arranz AM, De Strooper B. The role of astroglia in Alzheimer's disease: pathophysiology and clinical implications. Lancet Neurol 2019; 18(4): 406-414

37. Escartin C, Guillemaud O, Carrillo-de Sauvage MA. Questions and (some) answers on reactive astrocytes. Glia 2019; 67(12): 22212247

38. Howarth C, Gleeson P, Attwell D. Updated energy budgets for neural computation in the neocortex and cerebellum. J Cereb Blood Flow Metab 2012; 32(7): 1222-1232

39. Alberini CM, Cruz E, Descalzi G, Bessières B, Gao V. Astrocyte glycogen and lactate: new insights into learning and memory mechanisms. Glia 2018; 66(6): 1244-1262

40. Giaume C, Koulakoff A, Roux L, Holcman D, Rouach N. Astroglial networks: a step further in neuroglial and gliovascular interactions. Nat Rev Neurosci 2010; 11(2): 87-99

41. Koepsell H. Glucose transporters in brain in health and disease.
Pflugers Arch 2020; 472(9): 1299-1343

42. Calì C, Tauffenberger A, Magistretti P. The strategic location of glycogen and lactate: from body energy reserve to brain plasticity. Front Cell Neurosci 2019; 13: 82

43. Magistretti PJ, Allaman I. Lactate in the brain: from metabolic endproduct to signalling molecule. Nat Rev Neurosci 2018; 19(4): 235-249

44. Cunnane SC, Trushina E, Morland C, Prigione A, Casadesus G, Andrews ZB, Beal MF, Bergersen LH, Brinton RD, de la Monte S, Eckert A, Harvey J, Jeggo R, Jhamandas JH, Kann O, la Cour CM, Martin WF, Mithieux G, Moreira PI, Murphy MP, Nave KA, Nuriel T, Oliet SHR, Saudou F, Mattson MP, Swerdlow RH, Millan MJ. Brain energy rescue: an emerging therapeutic concept for neurodegenerative disorders of ageing. Nat Rev Drug Discov 2020; 19(9): 609-633

45. Juaristi I, Contreras L, González-Sánchez P, Pérez-Liébana I, González-Moreno L, Pardo B, Del Arco A, Satrústegui J. The response to stimulation in neurons and astrocytes. Neurochem Res 2019; 44(10): 2385-2391

46. Barros LF, Brown A, Swanson RA. Glia in brain energy metabolism: a perspective. Glia 2018; 66(6): 1134-1137

47. Dienel GA. Brain glucose metabolism: integration of energetics with function. Physiol Rev 2019; 99(1): 949-1045

48. Mächler P, Wyss MT, Elsayed M, Stobart J, Gutierrez R, von Faber-Castell A, Kaelin V, Zuend M, San Martín A, RomeroGómez I, Baeza-Lehnert F, Lengacher S, Schneider BL, Aebischer $\mathrm{P}$, Magistretti PJ, Barros LF, Weber B. In vivo evidence for a lactate gradient from astrocytes to neurons. Cell Metab 2016; 23(1): 94-102

49. Suzuki A, Stern SA, Bozdagi O, Huntley GW, Walker RH, Magistretti PJ, Alberini CM. Astrocyte-neuron lactate transport is required for long-term memory formation. Cell 2011; 144(5): 810 823

50. Brooks GA. The science and translation of lactate shuttle theory. Cell Metab 2018; 27(4): 757-785

51. Detka J, Kurek A, Kucharczyk M, Głombik K, Basta-Kaim A, Kubera M, Lasoń W, Budziszewska B. Brain glucose metabolism in an animal model of depression. Neuroscience 2015; 295: 198208

52. Yin YN, Hu J, Wei YL, Li ZL, Luo ZC, Wang RQ, Yang KX, Li SJ, Li XW, Yang JM, Gao TM. Astrocyte-derived lactate modulates the passive coping response to behavioral challenge in male mice. Neurosci Bull 2021; 37(1): 1-14

53. Murphy-Royal C, Johnston AD, Boyce AKJ, Diaz-Castro B, Institoris A, Peringod G, Zhang O, Stout RF, Spray DC, Thompson RJ, Khakh BS, Bains JS, Gordon GR. Stress gates an astrocytic energy reservoir to impair synaptic plasticity. Nat Commun 2020; 11(1): 2014

54. Carrard A, Elsayed M, Margineanu M, Boury-Jamot B, Fragnière L, Meylan EM, Petit JM, Fiumelli H, Magistretti PJ, Martin JL. Peripheral administration of lactate produces antidepressant-like effects. Mol Psychiatry 2018; 23(2): 392-399

55. Yang J, Ruchti E, Petit JM, Jourdain P, Grenningloh G, Allaman I, Magistretti PJ. Lactate promotes plasticity gene expression by potentiating NMDA signaling in neurons. Proc Natl Acad Sci USA 2014; 111(33): 12228-12233

56. Powell CL, Davidson AR, Brown AM. Universal glia to neurone 
lactate transfer in the nervous system: physiological functions and pathological consequences. Biosensors (Basel) 2020; 10(11): E183

57. Karnib N, El-Ghandour R, El Hayek L, Nasrallah P, Khalifeh M, Barmo N, Jabre V, Ibrahim P, Bilen M, Stephan JS, Holson EB, Ratan RR, Sleiman SF. Lactate is an antidepressant that mediates resilience to stress by modulating the hippocampal levels and activity of histone deacetylases. Neuropsychopharmacology 2019; 44(6):1152-1162

58. Bak LK, Walls AB. CrossTalk opposing view: lack of evidence supporting an astrocyte-to-neuron lactate shuttle coupling neuronal activity to glucose utilisation in the brain. J Physiol 2018; 596(3): 351-353

59. Dienel GA. Lack of appropriate stoichiometry: strong evidence against an energetically important astrocyte-neuron lactate shuttle in brain. J Neurosci Res 2017; 95(11): 2103-2125

60. Lipmann F. Metabolic Generation and Utilization of Phosphate Bond Energy. John Wiley \& Sons, Inc., 2006

61. Mori M, Heuss C, Gähwiler BH, Gerber U. Fast synaptic transmission mediated by $\mathrm{P} 2 \mathrm{X}$ receptors in CA3 pyramidal cells of rat hippocampal slice cultures. J Physiol 2001; 535(1): 115-123

62. Pankratov Y, Lalo U, Krishtal O, Verkhratsky A. Ionotropic P2X purinoreceptors mediate synaptic transmission in rat pyramidal neurones of layer II/III of somato-sensory cortex. J Physiol 2002; 542(2): 529-536

63. Cao X, Li LP, Wang Q, Wu Q, Hu HH, Zhang M, Fang YY, Zhang J, Li SJ, Xiong WC, Yan HC, Gao YB, Liu JH, Li XW, Sun LR, Zeng YN, Zhu XH, Gao TM. Astrocyte-derived ATP modulates depressive-like behaviors. Nat Med 2013; 19(6): 773-777

64. Bansal Y, Kuhad A. Mitochondrial dysfunction in depression. Curr Neuropharmacol 2016; 14(6): 610-618

65. Nakamura Y, Park JH, Hayakawa K. Therapeutic use of extracellular mitochondria in CNS injury and disease. Exp Neurol 2020; 324: 113114

66. Illes P, Rubini P, Yin H, Tang Y. Impaired ATP release from brain astrocytes may be a cause of major depression. Neurosci Bull 2020; 36(11): 1281-1284

67. Rajani V, Zhang Y, Jalubula V, Rancic V, SheikhBahaei S, Zwicker JD, Pagliardini S, Dickson CT, Ballanyi K, Kasparov S, Gourine AV, Funk GD. Release of ATP by pre-Bötzinger complex astrocytes contributes to the hypoxic ventilatory response via a $\mathrm{Ca}^{2+}$-dependent $\mathrm{P}_{2} \mathrm{Y}_{1}$ receptor mechanism. J Physiol 2018; 596(15): 3245-3269

68. Halassa MM, Fellin T, Haydon PG. Tripartite synapses: roles for astrocytic purines in the control of synaptic physiology and behavior. Neuropharmacology 2009; 57(4): 343-346

69. Cai W, Xue C, Sakaguchi M, Konishi M, Shirazian A, Ferris HA, Li ME, Yu R, Kleinridders A, Pothos EN, Kahn CR. Insulin regulates astrocyte gliotransmission and modulates behavior. J Clin Invest 2018; 128(7): 2914-2926

70. Choi W, Clemente N, Sun W, Du J, Lü W. The structures and gating mechanism of human calcium homeostasis modulator 2. Nature 2019; 576(7785): 163-167

71. Syrjanen JL, Michalski K, Chou TH, Grant T, Rao S, Simorowski N, Tucker SJ, Grigorieff N, Furukawa H. Structure and assembly of calcium homeostasis modulator proteins. Nat Struct Mol Biol 2020; 27(2): 150-159

72. Ma J, Qi X, Yang C, Pan R, Wang S, Wu J, Huang L, Chen H,
Cheng J, Wu R, Liao Y, Mao L, Wang FC, Wu Z, An JX, Wang Y, Zhang X, Zhang C, Yuan Z. Calhm2 governs astrocytic ATP releasing in the development of depression-like behaviors. Mol Psychiatry 2018; 23(4): 883-891

73. Dreses-Werringloer U, Lambert JC, Vingtdeux V, Zhao H, Vais H, Siebert A, Jain A, Koppel J, Rovelet-Lecrux A, Hannequin D, Pasquier F, Galimberti D, Scarpini E, Mann D, Lendon C, Campion D, Amouyel P, Davies P, Foskett JK, Campagne F, Marambaud P. A polymorphism in CALHM1 influences $\mathrm{Ca}^{2+}$ homeostasis, $\mathrm{A} \beta$ levels, and Alzheimer's disease risk. Cell 2008; 133(7): 1149-1161

74. Taruno A, Vingtdeux V, Ohmoto M, Ma Z, Dvoryanchikov G, Li A, Adrien L, Zhao H, Leung S, Abernethy M, Koppel J, Davies P, Civan MM, Chaudhari N, Matsumoto I, Hellekant G, Tordoff MG, Marambaud P, Foskett JK. CALHM1 ion channel mediates purinergic neurotransmission of sweet, bitter and umami tastes. Nature 2013; 495(7440): 223-226

75. Rial D, Lemos C, Pinheiro H, Duarte JM, Gonçalves FQ, Real JI, Prediger RD, Gonçalves N, Gomes CA, Canas PM, Agostinho P, Cunha RA. Depression as a glial-based synaptic dysfunction. Front Cell Neurosci 2016; 9: 521

76. Trautmann A. Extracellular ATP in the immune system: more than just a "danger signal". Sci Signal 2009; 2(56): pe6

77. Janks L, Sharma CVR, Egan TM. A central role for P2X7 receptors in human microglia. J Neuroinflammation 2018; 15(1): 325

78. Iwata M, Ota KT, Li XY, Sakaue F, Li N, Dutheil S, Banasr M, Duric V, Yamanashi T, Kaneko K, Rasmussen K, Glasebrook A, Koester A, Song D, Jones KA, Zorn S, Smagin G, Duman RS. Psychological stress activates the inflammasome via release of adenosine triphosphate and stimulation of the purinergic type $2 \mathrm{X} 7$ receptor. Biol Psychiatry 2016; 80(1): 12-22

79. Illes P, Verkhratsky A, Tang Y. Pathological ATPergic signaling in major depression and bipolar disorder. Front Mol Neurosci 2020; 12: 331

80. Farooq RK, Tanti A, Ainouche S, Roger S, Belzung C, Camus V. A P2X7 receptor antagonist reverses behavioural alterations, microglial activation and neuroendocrine dysregulation in an unpredictable chronic mild stress (UCMS) model of depression in mice. Psychoneuroendocrinology 2018; 97: 120-130

81. Yue N, Huang H, Zhu X, Han Q, Wang Y, Li B, Liu Q, Wu G, Zhang Y, Yu J. Activation of P2X7 receptor and NLRP3 inflammasome assembly in hippocampal glial cells mediates chronic stress-induced depressive-like behaviors. J Neuroinflammation 2017; 14(1): 102

82. Rodrigues RJ, Tomé AR, Cunha RA. ATP as a multi-target danger signal in the brain. Front Neurosci 2015; 9: 148

83. Wang C, Yin Q, Su Z, Xia L. Progress on role of extracellular ATP and its metabolite adenosine in immunoregulation: review. Chin J Cell Mol Immunol (Xi Bao Yu Fen Zi Mian Yi Xue Za Zhi) 2020; 36(12):1134-1140 (in Chinese)

84. Schain M, Kreisl WC. Neuroinflammation in neurodegenerative disorders-a review. Curr Neurol Neurosci Rep 2017; 17(3): 25

85. Shabab T, Khanabdali R, Moghadamtousi SZ, Kadir HA, Mohan G. Neuroinflammation pathways: a general review. Int J Neurosci 2017; 127(7): 624-633

86. Colombo E, Farina C. Astrocytes: key regulators of neuroinflammation. Trends Immunol 2016; 37(9): 608-620 
87. Faulkner JR, Herrmann JE, Woo MJ, Tansey KE, Doan NB, Sofroniew MV. Reactive astrocytes protect tissue and preserve function after spinal cord injury. J Neurosci 2004; 24(9): 21432155

88. Myer DJ, Gurkoff GG, Lee SM, Hovda DA, Sofroniew MV. Essential protective roles of reactive astrocytes in traumatic brain injury. Brain 2006; 129(10): 2761-2772

89. Voskuhl RR, Peterson RS, Song B, Ao Y, Morales LB, TiwariWoodruff S, Sofroniew MV. Reactive astrocytes form scar-like perivascular barriers to leukocytes during adaptive immune inflammation of the CNS. J Neurosci 2009; 29(37): 11511-11522

90. Mayo L, Trauger SA, Blain M, Nadeau M, Patel B, Alvarez JI, Mascanfroni ID, Yeste A, Kivisäkk P, Kallas K, Ellezam B, Bakshi R, Prat A, Antel JP, Weiner HL, Quintana FJ. Regulation of astrocyte activation by glycolipids drives chronic CNS inflammation. Nat Med 2014; 20(10): 1147-1156

91. Brites D, Fernandes A. Neuroinflammation and depression: microglia activation, extracellular microvesicles and microRNA dysregulation. Front Cell Neurosci 2015; 9: 476

92. Troubat R, Barone P, Leman S, Desmidt T, Cressant A, Atanasova B, Brizard B, El Hage W, Surget A, Belzung C, Camus V. Neuroinflammation and depression: a review. Eur J Neurosci 2021; 53(1): 151-171

93. Cernackova A, Durackova Z, Trebaticka J, Mravec B. Neuroinflammation and depressive disorder: the role of the hypothalamus. J Clin Neurosci 2020; 75: 5-10

94. Zheng ZH, Tu JL, Li XH, Hua Q, Liu WZ, Liu Y, Pan BX, Hu P, Zhang WH. Neuroinflammation induces anxiety- and depressivelike behavior by modulating neuronal plasticity in the basolateral amygdala. Brain Behav Immun 2021; 91: 505-518

95. Ali T, Rahman SU, Hao Q, Li W, Liu Z, Ali Shah F, Murtaza I, Zhang Z, Yang X, Liu G, Li S. Melatonin prevents neuroinflammation and relieves depression by attenuating autophagy impairment through FOXO3a regulation. J Pineal Res 2020; 69(2): e12667

96. Li W, Ali T, He K, Liu Z, Shah FA, Ren Q, Liu Y, Jiang A, Li S. Ibrutinib alleviates LPS-induced neuroinflammation and synaptic defects in a mouse model of depression. Brain Behav Immun 2021; 92: $10-24$

97. Walker AK, Wing EE, Banks WA, Dantzer R. Leucine competes with kynurenine for blood-to-brain transport and prevents lipopolysaccharide-induced depression-like behavior in mice. Mol Psychiatry 2019; 24(10): 1523-1532

98. Zhang Y, Du L, Bai Y, Han B, He C, Gong L, Huang R, Shen L, Chao J, Liu P, Zhang H, Zhang H, Gu L, Li J, Hu G, Xie C, Zhang Z, Yao H. CircDYM ameliorates depressive-like behavior by targeting miR-9 to regulate microglial activation via HSP90 ubiquitination. Mol Psychiatry 2020; 25(6): 1175-1190

99. Leng L, Zhuang K, Liu Z, Huang C, Gao Y, Chen G, Lin H, Hu Y, Wu D, Shi M, Xie W, Sun H, Shao Z, Li H, Zhang K, Mo W, Huang TY, Xue M, Yuan Z, Zhang X, Bu G, Xu H, Xu Q, Zhang J. Menin deficiency leads to depressive-like behaviors in mice by modulating astrocyte-mediated neuroinflammation. Neuron 2018; 100(3): 551-563.e7

100. Wu Y, Qiu A, Yang Z, Wu J, Li X, Bao K, Wang M, Wu B. Malva sylvestris extract alleviates the astrogliosis and inflammatory stress in LPS-induced depression mice. J Neuroimmunol 2019; 336:
577029

101. Wang Y, Ni J, Zhai L, Gao C, Xie L, Zhao L, Yin X. Inhibition of activated astrocyte ameliorates lipopolysaccharide-induced depressive-like behaviors. J Affect Disord 2019; 242: 52-59

102. Zhang HY, Wang Y, He Y, Wang T, Huang XH, Zhao CM, Zhang L, Li SW, Wang C, Qu YN, Jiang XX. A1 astrocytes contribute to murine depression-like behavior and cognitive dysfunction, which can be alleviated by IL-10 or fluorocitrate treatment. J Neuroinflammation 2020; 17(1): 200

103. Zimmer ER, Leuzy A, Benedet AL, Breitner J, Gauthier S, RosaNeto P. Tracking neuroinflammation in Alzheimer's disease: the role of positron emission tomography imaging. J Neuroinflammation 2014; 11(1): 120

104. Frost GR, Li YM. The role of astrocytes in amyloid production and Alzheimer's disease. Open Biol 2017; 7(12): 170228

105. Panza F, Lozupone M, Logroscino G, Imbimbo BP. A critical appraisal of amyloid- $\beta$-targeting therapies for Alzheimer disease. Nat Rev Neurol 2019; 15(2): 73-88

106. Verkhratsky A, Parpura V, Rodriguez-Arellano JJ, Zorec R. Astroglia in Alzheimer's disease. Adv Exp Med Biol 2019; 1175: 273-324

107. Serrano-Pozo A, Muzikansky A, Gómez-Isla T, Growdon JH, Betensky RA, Frosch MP, Hyman BT. Differential relationships of reactive astrocytes and microglia to fibrillar amyloid deposits in Alzheimer disease. J Neuropathol Exp Neurol 2013; 72(6): 462471

108. Okabe Y, Takahashi T, Mitsumasu C, Kosai K, Tanaka E, Matsuishi T. Alterations of gene expression and glutamate clearance in astrocytes derived from an MeCP2-null mouse model of Rett syndrome. PLoS One 2012; 7(4): e35354

109. Tagarelli A, Piro A, Tagarelli G, Lagonia P, Quattrone A. Alois Alzheimer: a hundred years after the discovery of the eponymous disorder. Int J Biomed Sci 2006; 2(2): 196-204

110. Ahmad MH, Fatima M, Mondal AC. Influence of microglia and astrocyte activation in the neuroinflammatory pathogenesis of Alzheimer's disease: rational insights for the therapeutic approaches. J Clin Neurosci 2019; 59: 6-11

111. Carter SF, Herholz K, Rosa-Neto P, Pellerin L, Nordberg A, Zimmer ER. Astrocyte biomarkers in Alzheimer's disease. Trends Mol Med 2019; 25(2): 77-95

112. Li S, Jin M, Koeglsperger T, Shepardson NE, Shankar GM, Selkoe DJ. Soluble A $\beta$ oligomers inhibit long-term potentiation through a mechanism involving excessive activation of extrasynaptic NR2Bcontaining NMDA receptors. J Neurosci 2011; 31(18): 6627-6638

113. Liddelow SA, Guttenplan KA, Clarke LE, Bennett FC, Bohlen CJ, Schirmer L, Bennett ML, Münch AE, Chung WS, Peterson TC, Wilton DK, Frouin A, Napier BA, Panicker N, Kumar M, Buckwalter MS, Rowitch DH, Dawson VL, Dawson TM, Stevens B, Barres BA. Neurotoxic reactive astrocytes are induced by activated microglia. Nature 2017; 541(7638): 481-487

114. Rossner S, Lange-Dohna C, Zeitschel U, Perez-Polo JR. Alzheimer's disease $\beta$-secretase BACE1 is not a neuron-specific enzyme. J Neurochem 2005; 92(2): 226-234

115. Veeraraghavalu K, Zhang C, Zhang X, Tanzi RE, Sisodia SS. Agedependent, non-cell-autonomous deposition of amyloid from synthesis of $\beta$-amyloid by cells other than excitatory neurons. J Neurosci 2014; 34(10): 3668-3673 
116. Brunello CA, Merezhko M, Uronen RL, Huttunen HJ. Mechanisms of secretion and spreading of pathological tau protein. Cell Mol Life Sci 2020; 77(9): 1721-1744

117. Gao Y, Tan L, Yu JT, Tan L. Tau in Alzheimer's disease: mechanisms and therapeutic strategies. Curr Alzheimer Res 2018; 15(3): 283-300

118. van der Kant R, Goldstein LSB, Ossenkoppele R. Amyloid- $\beta$ independent regulators of tau pathology in Alzheimer disease. Nat Rev Neurosci 2020; 21(1): 21-35

119. Kovacs GG. Astroglia and tau: new perspectives. Front Aging Neurosci 2020; 12: 96

120. Allen M, Wang X, Serie DJ, Strickland SL, Burgess JD, Koga S, Younkin CS, Nguyen TT, Malphrus KG, Lincoln SJ, Alamprese M, Zhu K, Chang R, Carrasquillo MM, Kouri N, Murray ME, Reddy JS, Funk C, Price ND, Golde TE, Younkin SG, Asmann YW, Crook JE, Dickson DW, Ertekin-Taner N. Divergent brain gene expression patterns associate with distinct cell-specific tau neuropathology traits in progressive supranuclear palsy. Acta Neuropathol 2018; 136(5): 709-727

121. Buée L, Bussière T, Buée-Scherrer V, Delacourte A, Hof PR. Tau protein isoforms, phosphorylation and role in neurodegenerative disorders. Brain Res Brain Res Rev 2000; 33(1): 95-130

122. Adams SJ, DeTure MA, McBride M, Dickson DW, Petrucelli L. Three repeat isoforms of tau inhibit assembly of four repeat tau filaments. PLoS One 2010; 5(5): e10810

123. Richetin K, Steullet P, Pachoud M, Perbet R, Parietti E, Maheswaran M, Eddarkaoui S, Bégard S, Pythoud C, Rey M, Caillierez R, Q Do K, Halliez S, Bezzi P, Buée L, Leuba G, Colin $\mathrm{M}$, Toni N, Déglon N. Tau accumulation in astrocytes of the dentate gyrus induces neuronal dysfunction and memory deficits in Alzheimer's disease. Nat Neurosci 2020; 23(12): 1567-1579

124. Bussian TJ, Aziz A, Meyer CF, Swenson BL, van Deursen JM, Baker DJ. Clearance of senescent glial cells prevents taudependent pathology and cognitive decline. Nature 2018; 562(7728): 578-582

125. Newington JT, Harris RA, Cumming RC. Reevaluating metabolism in Alzheimer's disease from the perspective of the astrocyteneuron lactate shuttle model. J Neurodegener Dis 2013; 2013: 234572

126. Zhang M, Cheng X, Dang R, Zhang W, Zhang J, Yao Z. Lactate deficit in an Alzheimer disease mouse model: the relationship with neuronal damage. J Neuropathol Exp Neurol 2018; 77(12): 1163 1176

127. Pal S, Paul S. ATP controls the aggregation of $A \beta_{16-22}$ peptides. J Phys Chem B 2020; 124(1): 210-223

128. Jung ES, An K, Hong HS, Kim JH, Mook-Jung I. Astrocyteoriginated ATP protects $A \beta(1-42)$-induced impairment of synaptic plasticity. J Neurosci 2012; 32(9): 3081-3087

129. Park JC, Han SH, Mook-Jung I. Peripheral inflammatory biomarkers in Alzheimer's disease: a brief review. BMB Rep 2020; 53(1): 10-19

130. Heneka MT, Carson MJ, El Khoury J, Landreth GE, Brosseron F, Feinstein DL, Jacobs AH, Wyss-Coray T, Vitorica J, Ransohoff RM, Herrup K, Frautschy SA, Finsen B, Brown GC, Verkhratsky A, Yamanaka K, Koistinaho J, Latz E, Halle A, Petzold GC, Town T, Morgan D, Shinohara ML, Perry VH, Holmes C, Bazan NG, Brooks DJ, Hunot S, Joseph B, Deigendesch N, Garaschuk O,
Boddeke E, Dinarello CA, Breitner JC, Cole GM, Golenbock DT, Kummer MP. Neuroinflammation in Alzheimer's disease. Lancet Neurol 2015; 14(4): 388-405

131. Fakhoury M. Microglia and astrocytes in Alzheimer's disease: implications for therapy. Curr Neuropharmacol 2018; 16(5): 508518

132. Pereira CF, Santos AE, Moreira PI, Pereira AC, Sousa FJ, Cardoso SM, Cruz MT. Is Alzheimer's disease an inflammasomopathy? Ageing Res Rev 2019; 56: 100966

133. Kaur D, Sharma V, Deshmukh R. Activation of microglia and astrocytes: a roadway to neuroinflammation and Alzheimer's disease. Inflammopharmacology 2019; 27(4): 663-677

134. Furman JL, Sama DM, Gant JC, Beckett TL, Murphy MP, Bachstetter AD, Van Eldik LJ, Norris CM. Targeting astrocytes ameliorates neurologic changes in a mouse model of Alzheimer's disease. J Neurosci 2012; 32(46): 16129-16140

135. Katsouri L, Birch AM, Renziehausen AWJ, Zach C, Aman Y, Steeds H, Bonsu A, Palmer EOC, Mirzaei N, Ries M, Sastre M. Ablation of reactive astrocytes exacerbates disease pathology in a model of Alzheimer's disease. Glia 2020; 68(5): 1017-1030

136. Shu X, Sun Y, Sun X, Zhou Y, Bian Y, Shu Z, Ding J, Lu M, Hu G. The effect of fluoxetine on astrocyte autophagy flux and injured mitochondria clearance in a mouse model of depression. Cell Death Dis 2019; 10(8): 577

137. Belujon P, Grace AA. Dopamine system dysregulation in major depressive disorders. Int J Neuropsychopharmacol 2017; 20(12): 1036-1046

138. Koppel I, Jaanson K, Klasche A, Tuvikene J, Tiirik T, Pärn A, Timmusk T. Dopamine cross-reacts with adrenoreceptors in cortical astrocytes to induce BDNF expression, CREB signaling and morphological transformation. Glia 2018; 66(1): 206-216

139. Shao W, Zhang SZ, Tang M, Zhang XH, Zhou Z, Yin YQ, Zhou QB, Huang YY, Liu YJ, Wawrousek E, Chen T, Li SB, Xu M, Zhou JN, Hu G, Zhou JW. Suppression of neuroinflammation by astrocytic dopamine D2 receptors via $\alpha B$-crystallin. Nature 2013; 494(7435): 90-94

140. Shimizu M, Nishida A, Zensho H, Yamawaki S. Chronic antidepressant exposure enhances 5-hydroxytryptamine7 receptor-mediated cyclic adenosine monophosphate accumulation in rat frontocortical astrocytes. J Pharmacol Exp Ther 1996; 279(3): $1551-1558$

141. Whitaker-Azmitia PM, Clarke C, Azmitia EC. Localization of 5HT1A receptors to astroglial cells in adult rats: implications for neuronal-glial interactions and psychoactive drug mechanism of action. Synapse 1993; 14(3): 201-205

142. Corkrum M, Covelo A, Lines J, Bellocchio L, Pisansky M, Loke K, Quintana R, Rothwell PE, Lujan R, Marsicano G, Martin ED, Thomas MJ, Kofuji P, Araque A. Dopamine-evoked synaptic regulation in the nucleus accumbens requires astrocyte activity. Neuron 2020; 105(6): 1036-1047.e5

143. Inazu M, Takeda H, Ikoshi $H$, Sugisawa M, Uchida $Y$, Matsumiya T. Pharmacological characterization and visualization of the glial serotonin transporter. Neurochem Int 2001; 39(1): 39-49

144. Zhou X, Xiao Q, Xie L, Yang F, Wang L, Tu J. Astrocyte, a promising target for mood disorder interventions. Front Mol Neurosci 2019; 12: 136

145. Kinoshita M, Hirayama Y, Fujishita K, Shibata K, Shinozaki Y, 
Shigetomi E, Takeda A, Le HPN, Hayashi H, Hiasa M, Moriyama Y, Ikenaka K, Tanaka KF, Koizumi S. Anti-depressant fluoxetine reveals its therapeutic effect via astrocytes. EBioMedicine 2018; 32: $72-83$

146. Park YM, Lee BH. Alterations in serum BDNF and GDNF levels after 12 weeks of antidepressant treatment in female outpatients with major depressive disorder. Psychiatry Investig 2018; 15(8): $818-823$

147. Niwa M, Nitta A, Yamada Y, Nakajima A, Saito K, Seishima M, Shen L, Noda Y, Furukawa S, Nabeshima T. An inducer for glial cell line-derived neurotrophic factor and tumor necrosis factor- $\alpha$ protects against methamphetamine-induced rewarding effects and sensitization. Biol Psychiatry 2007; 61(7): 890-901

148. Lu L, Wang X, Wu P, Xu C, Zhao M, Morales M, Harvey BK, Hoffer BJ, Shaham Y. Role of ventral tegmental area glial cell linederived neurotrophic factor in incubation of cocaine craving. Biol Psychiatry 2009; 66(2): 137-145

149. Fisher JR, Wallace CE, Tripoli DL, Sheline YI, Cirrito JR. Redundant Gs-coupled serotonin receptors regulate amyloid- $\beta$ metabolism in vivo. Mol Neurodegener 2016; 11(1): 45

150. Ma J, Gao Y, Jiang L, Chao FL, Huang W, Zhou CN, Tang W, Zhang L, Huang CX, Zhang Y, Luo YM, Xiao Q, Yu HR, Jiang R, Tang Y. Fluoxetine attenuates the impairment of spatial learning ability and prevents neuron loss in middle-aged APPswe/ PSEN1dE9 double transgenic Alzheimer's disease mice. Oncotarget 2017; 8(17): 27676-27692

151. Zhou CN, Chao FL, Zhang Y, Jiang L, Zhang L, Fan JH, Wu YX, Dou XY, Tang Y. Fluoxetine delays the cognitive function decline and synaptic changes in a transgenic mouse model of early Alzheimer's disease. J Comp Neurol 2019; 527(8): 1378-1387

152. Alexopoulos GS. Mechanisms and treatment of late-life depression. Transl Psychiatry 2019; 9(1): 188

153. Grace AA. Dysregulation of the dopamine system in the pathophysiology of schizophrenia and depression. Nat Rev Neurosci 2016; 17(8): 524-532

154. Pytka K, Podkowa K, Rapacz A, Podkowa A, Żmudzka E, Olczyk A, Sapa J, Filipek B. The role of serotonergic, adrenergic and dopaminergic receptors in antidepressant-like effect. Pharmacol Rep 2016; 68(2): 263-274

155. Kumar U, Patel SC. Immunohistochemical localization of dopamine receptor subtypes (D1R-D5R) in Alzheimer's disease brain. Brain Res 2007; 1131(1): 187-196

156. Pan X, Kaminga AC, Wen SW, Wu X, Acheampong K, Liu A. Dopamine and dopamine receptors in Alzheimer's disease: a systematic review and network meta-analysis. Front Aging Neurosci 2019; 11: 175

157. Koch G, Di Lorenzo F, Bonnì S, Giacobbe V, Bozzali M, Caltagirone C, Martorana A. Dopaminergic modulation of cortical plasticity in Alzheimer's disease patients. Neuropsychopharmacology. 2014; 39(11): 2654-2661

158. D'Amelio M, Puglisi-Allegra S, Mercuri N. The role of dopaminergic midbrain in Alzheimer's disease: translating basic science into clinical practice. Pharmacol Res 2018; 130: $414-419$
159. Krashia P, Nobili A, D'Amelio M. Unifying hypothesis of dopamine neuron loss in neurodegenerative diseases: focusing on Alzheimer's disease. Front Mol Neurosci 2019; 12: 123

160. Jha MK, Jo M, Kim JH, Suk K. Microglia-astrocyte crosstalk: an intimate molecular conversation. Neuroscientist 2019; 25(3): 227240

161. Molofsky AV, Deneen B. Astrocyte development: a guide for the perplexed. Glia 2015; 63(8): 1320-1329

162. Herbert J, Lucassen PJ. Depression as a risk factor for Alzheimer's disease: genes, steroids, cytokines and neurogenesis - what do we need to know? Front Neuroendocrinol 2016; 41: 153-171

163. Ownby RL, Crocco E, Acevedo A, John V, Loewenstein D. Depression and risk for Alzheimer disease: systematic review, meta-analysis, and metaregression analysis. Arch Gen Psychiatry 2006; 63(5): 530-538

164. Barlinn K, Kepplinger J, Puetz V, Illigens BM, Bodechtel U, Siepmann T. Exploring the risk-factor association between depression and incident stroke: a systematic review and metaanalysis. Neuropsychiatr Dis Treat 2014; 11: 1-14

165. Gan Y, Gong Y, Tong X, Sun H, Cong Y, Dong X, Wang Y, Xu X, Yin X, Deng J, Li L, Cao S, Lu Z. Depression and the risk of coronary heart disease: a meta-analysis of prospective cohort studies. BMC Psychiatry 2014; 14(1): 371

166. Troubat R, Barone P, Leman S, Desmidt T, Cressant A, Atanasova B, Brizard B, El Hage W, Surget A, Belzung C, Camus V. Neuroinflammation and depression: a review. Eur J Neurosci 2021; 53(1): $151-171$

167. Uddin MS, Kabir MT, Rahman MS, Behl T, Jeandet P, Ashraf GM, Najda A, Bin-Jumah MN, El-Seedi HR, Abdel-Daim MM. Revisiting the amyloid cascade hypothesis: from anti-A $\beta$ therapeutics to auspicious new ways for Alzheimer's disease. Int J Mol Sci 2020; 21(16): E5858

168. Wang Q, Jie W, Liu JH, Yang JM, Gao TM. An astroglial basis of major depressive disorder? An overview. Glia 2017; 65(8): 12271250

169. Han X, Chen M, Wang F, Windrem M, Wang S, Shanz S, Xu Q, Oberheim NA, Bekar L, Betstadt S, Silva AJ, Takano T, Goldman SA, Nedergaard M. Forebrain engraftment by human glial progenitor cells enhances synaptic plasticity and learning in adult mice. Cell Stem Cell 2013; 12(3): 342-353

170. Lepore AC, Rauck B, Dejea C, Pardo AC, Rao MS, Rothstein JD, Maragakis NJ. Focal transplantation-based astrocyte replacement is neuroprotective in a model of motor neuron disease. Nat Neurosci 2008; 11(11): 1294-1301

171. Qian H, Kang X, Hu J, Zhang D, Liang Z, Meng F, Zhang X, Xue Y, Maimon R, Dowdy SF, Devaraj NK, Zhou Z, Mobley WC, Cleveland DW, Fu XD. Reversing a model of Parkinson's disease with in situ converted nigral neurons. Nature 2020; 582(7813): 550-556

172. Zhou H, Su J, Hu X, Zhou C, Li H, Chen Z, Xiao Q, Wang B, Wu W, Sun Y, Zhou Y, Tang C, Liu F, Wang L, Feng C, Liu M, Li S, Zhang Y, Xu H, Yao H, Shi L, Yang H. Glia-to-neuron conversion by CRISPR-CasRx alleviates symptoms of neurological disease in mice. Cell 2020; 181(3): 590-603.e16 